\title{
In Vitro Studies on the Influence of Different Concentrations of Growth Regulators on Economically Important Orchid, Vanilla planifolia
}

\author{
Vijaykumar Biradar ${ }^{1 *}$, Ashashree Inamdar ${ }^{2}$, Aswini Shamse and M.S. Patil ${ }^{3}$ \\ ${ }^{1}$ PG Studies and Research Centre in Biotechnology, Karnatak College, \\ Bidar-585 401, Karnataka, India \\ ${ }^{2}$ Department of Biotechnology, Karnatak College, Bidar-585 401, Karnataka, India \\ ${ }^{3}$ Department of Botany, Karnatak College, Bidar-585 401, Karnataka, India
}

*Corresponding author

Keywords

Vanilla planifolia, Micropropagation, Growth regulators, BAP, Coconut water, Callus, MS medium.

\section{Article Info}

Accepted:

15 August 2016

Available Online:

10 September 2016

\section{A B S T R A C T}

Vanilla is propagated by stem-cuttings. Collection of stem-cuttings from the mother plants to arrest of growth, development and yield. In order to meet the demand for propagates, the rapid regeneration method of this species is essential. Micropropogation of Vanilla planifolia has been reported through callus culture, protocorn, root tips and axillary bud explants. Even though few reports are available on in vitro propagation, the protocols are complicated, hence in this report a simple, economical, rapidly multiplying and highly reproducible protocol for large scale micropropogation is made. In this work, the protocol developed for shoot tip culture of Vanilla Planifolia on Murashige and Skoog's medium supplemented with different growth regulators. In this experiment the shoot induction is studied on MS medium supplemented with different concentration of BAP, in which it is showing average leaf production on BA $0.5 \mathrm{mg} / \mathrm{liter}$. we have also studied effect of different concentration of BAP \& coconut water $(\mathrm{CW})$ on average leaf formation in which BAP $1.0 \mathrm{mg} /$ liter with $1.5 \%$ coconut water showing average leaf formation and also one of the MS basal medium which is supplemented with different growth regulators that is IAA, Kinetin, BAP, D-Biotin, Ca-Pentatrenate, is also showing the maximum leaf formation.

\section{Introduction}

There are 25,000 species of orchids in the world and many types are yet to be discovered, additionally there are about 6000 types of hybrid orchids have been created by growers.

\section{Systematic position of Vanilla planifolia}

$\begin{array}{lll}\text { Kingdom } & : & \text { Plantae } \\ \text { Subdivision } & : & \text { Tracheobionata } \\ \text { Division } & : & \text { Tragnoloiophyta } \\ \text { Sub-division } & : & \text { Spermatophyta } \\ \text { Class } & : & \text { Liliopsida }\end{array}$




$\begin{array}{lll}\text { Sub-class } & : & \text { Lilidae } \\ \text { Order } & : & \text { Orchidales } \\ \text { Family } & : & \text { Orchidaceae } \\ \text { Genus } & : & \text { Vanilla } \\ \text { Species } & : & \text { planifola }\end{array}$

\section{Distribution}

These orchids are mostly observed in Mexican countries. The climatic regions of India are reflected in the wide diversity of its orchid flora about 1600 species of orchids were recorded (Hooker's flora of British India). Kumar and Manilal (1994) reported nearly 1150 orchid species in India. In the Peninsular region, 75 genera and 315 species \& in Himalayan region, about 151 genera and 876 species of orchids are found. Some important genera reported from Peninsular India are Acampe, Aerides, Bulbophylum, cottani.7, Cymbidium, Diplocentrum, Eria Habenaric, Ipsea, Phalus, Rhyncostrylis, Vanilla etc.

The orchid Vanilla was first used by the Aziecs and the Maya in Mexico and Central America from where it originates, as the flavor for there 'Xocolatl'. It was introduced in Europe after Columbus and Cortez came to America and made popular by king of France. The Spanish conquistadors called Vanilla capsule when saw firstly it in Mexico. Most of the Vanilla today comes from outside countries such as Madagascar, Reunion and Tahiti. The Vanilla planifolia var. Fragrans (Salib) ames is native to Mexico spread into tropical regions in America, Africa (madagaskar) and Asia. In India it is grown in Nilgiris Coorg and Mysore.

Vanilla planifolia Andrews belongs to the family orchidaceae and is the only orchid of significant economic importance as an edible crop. The Vanilla genus contains about 110 species, all of them are distributed between latitude $27^{\circ}$ North and $27^{\circ}$ South on all continents expect Australia, under natural conditions, Vanilla climbs, covers its support, and flowers when it reaches the top of the canopy. Vanilla is a special kind of orchid, which, unlike its relatives, does not grow on branches and tree trunks but winds upwards out of the ground like a climbing plant. Its tendrils are attached to trees, poles or walls, which then grow new roots. It grows in hot, damp, tropical climates, at elevations from sea level to 2500 feet, where it can be protected from the wind, with an average annual rainfall of about 75 to 100 inches. The life span of the Vanilla is 12 to 14 years.

Vanilla planifolia Andrews, the only spicy orchid of the tropics is valued for its cured fragrant beans, which makes one of the most expensive spices second only to saffron. The plant, native of Mexico and Central America has been introduced to all parts of the tropics and grown extensively in Madagaskar, Reunion and Comoro Islands. India is one of the potential countries for Vanilla cultivation and it can be grow as intercrop in coconut and areca nut plantation and as an alternate crop in cardamom and coffee plantation. Vanilla plant is a vine, with long succulent green coloured stem and greenish white aerial roots growing from the opposite side of the leaves, by which it clings to the support. The plant is commercially propagated by stem cuttings which are properly reportedly uneconomical as it involves sacrifices of the whole plant.

\section{General features}

It is a climbing herb of Orchidaceae family, whose stem grows up to $30 \mathrm{~cm}$ long. Its aerial roots which it sticks to the tree that serves it as support. It has fleshy leaves and large blackish ochre pods with, many seeds. The vines are fleshy stems with luscious 
leaves that are $12 \mathrm{~cm}$ long. The vine can be $20 \mathrm{~cm}$ in diameter. The plant can reach a size of $20 \mathrm{~m}$ or more. The plant often blooms in the second year but it doesn't begin to fully produce until the third year. It cannot thrive in either dryness or strong winds, nor does it need excessive amounts of moisture. Partial shade is crucial and this is usually provided by the shrubs or small trees up which the vines are grown. Indian Vanilla planifolia Andrews species is commercially preferred as a source of vanillin and therefore widely cultivated. The vines are planted close to the base of the support tree. Planting in May-June or August-September depending on the intensity of rain will be ideal. Vanilla performs well under $50 \%$ shade condition.

\section{Vanilla growth}

The most suitable land for Vanilla is gently sloping, with light brittle soil, enough but not excessive drainage, and a thick surface layer of humus or mulch, which helps the roots to spread. The soil should be alluvial with an acidity $(\mathrm{pH})$ level 6.0. Vanilla Planifolia comes in two varieties the plain and the variegated form. The commercial Vanilla plant is usually $V$. planifolia or $V$. fragrans and other commercially cultivated members of the genus are Vanilla pompona, found in the West Indies and Vanilla tahitensis, is native to Central and South America, especially in Mexico, but are now cultivated in other tropical regions. It is successfully grown in kerala, Karnataka, Andaman\& Nicobar Islands, Tamilnadu, Coastal A.P. and N.E. regions of India.

Vanilla needs lot of organic matter for proper growth. Roots are very tender confining to surface layer of soil it should be damaged by any cultural operations. Weekly irrigation of two to three liters of water per plant is enough. The vines may be allowed to grow to a height of 1.20 to 1.50 meter and allowed to hang down. Such branches should be brought back to the ground and a portion is placed under the mulch. Later it is brought up by providing support. Thus the vines are trailed up and down for the $1^{\text {st }}$ two years so that the plant produces enough vines to form bearing branches. Natural pollination in vanilla is difficult as stigma is prevented from coming into contact with another by a flap like projection known as "rostellum". So, artificial hand pollination is a must for production of beans.

\section{Economic importance of orchids}

Mostly the orchids are known for their ornamental value. Vanilla the only orchid, grown for source of spices. From this plant a flavoring substance is obtained from the dried full sized but unripe fruits. The active principle of vanilla is vanilloside a glycoside which during the drying process becomes vanillin. Vanilla is due to the crystalline substance vanillin which gives aroma to favorite drinks, made with cocoa grains and corn flour, \& also flavoring for ice creams, soft drinks, chocolate, confectionary, candy, pudding, cookies and also perfumery. The world demand of Vanilla beans is nearly 20,000 tons per annum.

In some African countries over 25 species are used in traditional medicine. Vanilla has stomachic, digestive, chloretic (increasing bile secretion) mildly invigorating. According to some people vanilla is used as Vanilla sugar, syrup, or tincture. However the most important usual method obtains its authentic aroma is by boiling its pods with the substance you want to flavor i.e. chocolate, infusions, desserts. It is also used in increase cones, air fresheners, and room deodorizing sprays candles, body lotions, soaps, shampoos, conditioners, and bath and shower gels. 
Various types of vanilla products used in flavoring application

\section{Vanilla extract}

This is a hydro alcoholic solution containing the extracted aroma and flavor of vanilla beans. Vanilla extract may be prepared by direct extraction (maceration) or by dilution of concentrated vanilla extract, concentrated vanilla flavoring or vanilla oleoresin.

\section{Vanilla flavoring}

This is similar to 'vanilla extract' but contains less than $35 \%$ ethyl alcohol by volume.

\section{Vanilla tincture}

This is prepared by maceration from I part of vanilla beans by weight to 10 parts of aqueous alcohol by volume and contains added sugar. It differs from 'vanilla extract' in having an ethyl alcohol content of at least $38 \%$. It is mainly used for pharmaceutical purposes.

Concentrated vanilla extract and concentrated vanilla flavoring: these products are prepared by stripping off a part of the solvent from solvent extracts to concentrate the vanilla constituent content. They have the same alcohol content as the corresponding vanilla extract or vanilla flavoring.

Vanilla oleoresin: This is a semi-solid concentrate obtained by removal of the solvent from a vanilla extract. Aqueous isopropanol is frequently used in stead of aqueous ethyl alcohol for the extraction.

Vanilla-vanillin extract and flavoring: These products are fortified with synthetic vanillin and the natural component is usually obtained by dilution of vanilla oleoresin.
Vanilla powder: This may be pure powdered vanilla but it is more usually a mixture of vanilla powder or vanilla oleoresin with sugar, food starch or gum acacia.

\section{Plant cell and tissue culture}

Plant cell and tissue culture is an important tool in both basic and applied sciences, including plant breeding. It also has vast number of commercial applications. Haberlandt in 1902 suggested the possibility of culturing artificial embryos from vegetative cells. $\mathrm{He}$ conceived and enunciated the concept of "totipotency" i.e. all the living cells containing a normal complement of chromosomes should be capable of regenerating into entire plant. He visualized growing plant cells in artificial media to rejuvenate quiescent and differentiated cells to trigger them division and growth, forming tissue, regenerating a mature plant.

Skoog and Miller (1957) demonstrated that regulation and differentiation of shoots and roots (organogenesis) in Vanilla planifolia pith cultures depend on the relative concentration of the auxin, cytokinin, thus introducing the concept hormonal control of organ formation. Their results became the guiding principles of in vitro organogenesis.

Auxins and Cytokinins established the basis for manipulating, organ initiation and provided the principles on which micro propagation depends. Other important development include regeneration of somatic embryos from the callus cells suspension (George et. al., 1964), protoplast isolation technique by Cocking (1960) and artificial hybridization of plant protoplast in aseptic culture by Carlson et. al., (1972). Development of nutrient media for Tissue culture of Vanilla planifolia by Murashige and Skoog (1962) was a great achievement 
in tissue culture. This media is now accepted world wide as the classic nutrient media for the tissue culture of most of the species.

Tissue culture has wide applications in the field of plant breeding, genetic engineering, biotechnology and conservation of endangered plant species. They are i) mass multiplication of commercially important plants by Micropropogation, ii) tissue culture technique can be used for the production of disease free plants, iii) it is having important application for the production of the haploids through anther culture, iv) plant tissue culture technique is used in production of secondary metabolic products such as alkaloids, glycosides, antibiotics, etc., v) in mutant selection useful , mutated cell is selected and can be cultured to get desirable characters, vi)protoplast culture is used for the product of clones, somatic hybrids and for the direct DNA uptake, vi) tissue culture has great importance in germplasm conservation, vii) plant tissue culture is used for the propagation of plants that are difficult to spread because of climatic and geographical barriers, viii)tissue culture has great significance in pathological studies, ix) plants which having more dormancy period such plant can be raised through plant tissue culture, \& x) in this technique whole plant is obtained from single isolated cells.

\section{Micro propagation}

Many plants are increased in number by detaching their parts, planting them in appropriate potting medium and growing the parts into individual plants. This kind of plant propagation, otherwise called vegetative propagation or clonal propagation. Vegetative propagation is widely followed by nursery men all over the world and has greatly contributed to horticulture and floriculture. However, this method uses large parts of pieces of plants and may be slow and cumbersome to realize commercial quantities of plants within specified period. Often it requires large area and its success may be limited by seasonal influences. Certain plants do not respond to vegetative propagation at all, while in others, only the juvenile plants whose agronomic traits cannot be assessed in advance respond favorably. In many vegetatively propagated crops like cardamom, pepper and cassava, pathogens are easily carried and spread through vegetative propagules.

Botanical tissue culture offers the gardeners an alternative or an adjunct to convention vegetative propagation. Tissue culture in general refers to the cultivation of small, even microscopic pieces of the plant especially those containing meristematic cells in suitable nutrient media under controlled environment conditions. A nutrient medium is a formulation containing inorganic saults, organic substances, sugar, and plant growth regulator(s). Tissue cultures are usually incubated in a culture room maintained at $25 \pm 1{ }^{\circ} \mathrm{C}$ under appropriate photoperiods, the illumination being provided by a blank of fluorescent tubes at 1500-2000 lux.

Micro propagation through tissue culture is an advanced method of vegetative propagation which enables rapid multiplication of meristems and bulking of plant propagation which enables rapid multiplication of meristems and bulking of plants propagules at a desired place. The meristem in culture may be as small as a cell group of cells, a shoot tip or as big as steam cutting measuring a few centimeters. The meristematic cells or tissues in culture differentiate and develop into shoots and roots and individual plantlets are the separated and transferred to the nursery. In 
most instances, micro propagations results in rapid multiplication bulking of the existing genotype and therefore, the regenerated plants are genetically uniform. Thus far, the demonstrated ability (totipotency) of plant cells and tissue culture to unfold their morphogenetic potential and to produce carban copies of the mother plant, has been demonstrated in viz., development of resident meristems into plants remains the same,although the conditions under which the tissues are nurtured and the speed and space in which the plants multiply differ. It will not be surprising if 1-2 millions plantlets are produced from a single shoot tip culture of a plant within a year.

\section{Chief advantages of Micro Propagation}

1. Production and maintenance of large number of plants in limited space and time.

2. Disease elimination and release of certified virus free plants (apical meristem culture).

3. High propagation is bulking of most recent selections and release of the some quickly and widely.

4. Production throughout the year independent of seasonal influences.

5. Propagation of plants that is otherwise difficult to propagate.

6. Prolonged storage of tissues for future use.

7. No attention of the plants between subcultures there by saving labour and materials for watering, weeding, spraying etc.

\section{Plant growth regulators \& their role in culture}

Some chemicals occurring naturally within plant tissue (i.e. endogenously) have a regulatory rather than nutritional role in growth and development. Growth as well as differentiation of tissue in vitro is controlled by various growth regulators Auxins, Cytokinin, Gibberllins, Ethylene, Abscisic acid etc.

Auxins: Auxin (IAA, NAA, 2, 4-D, IBA) are phytohormones that influence cell enlargement, root initiation, adventitious bud formation. They suppress the initiation of lateral buds.

2,4-D (2,4 dichlorophenoxy acetic acid : $\mathrm{C}_{8} \mathrm{H}_{6} \mathrm{C}_{12} \mathrm{O}_{3}$ ) is a synthetic auxin known primarily as a weed killer. It is used for callus induction.

IAA ( Indole -3-acetic acid: $\mathrm{C}_{10} \mathrm{H}_{9} \mathrm{NO}_{2}$ ). It is a promoter rooting of cuttings.

IBA ( Indole -3-butyric acid: $\mathrm{C}_{12} \mathrm{H}_{13} \mathrm{NO}_{2}$ ). It is rooting hormone and more stable than IAA.

NAA (1-Napthalene acetic acid: $\mathrm{C}_{12} \mathrm{H}_{16} \mathrm{O}_{2}$ ). It is also a root-inducing hormone and also promoters callus growth.

Cytokinins: (The cytokinin (KN, BAP, ZIP and Zeatin) is a adenine derivatives and is formerly called Kinins.

BAP ( 6-Benzyl Amino Purine: $\mathrm{C}_{12} \mathrm{H}_{11} \mathrm{~N}_{5}$ ). It is a used to promote axillary bud growth. 2IPA ( IPA:6 [0,0 Dimethyl amino] Purine or N6-(2-iso Pentyl)] no;C10 H13 N5 ).It causes rapid cell division and consequent irregular growth

Kinetin (6- furfurylaminopurine: $\mathrm{C}_{10} \mathrm{H}_{9} \mathrm{~N}_{5} \mathrm{O}$ ). It promotes cell division.

Zeatin [6 (4-hydroxy-3-methyl but-2enlyaminopurine: $\mathrm{C}_{10} \mathrm{H}_{13} \mathrm{~N}_{5} \mathrm{O}$ ). It is a common alternative cytokinin to 2IPA.

Cytokinins are even effective in promoting direct or indirect shoot initiation Wickson 
and Thimann (1958) discovered that Cytokinin could release the lateral buds from apical dominance in an intact stem tip. The role of cytokinin in shoot organogenesis is well-established (Flick et.al. 1983). But BAP was more effective than cyokinins in promoting Shoot proliferation (Chin Yi Lu, 1993). Bai \& Qu (2001) reported that calli induced on 6-benzylaminopurine (BAP)containing medium had significantly improved regeneration ability.

Gibberllins: Gibberllins (gibberllic acid, GA3C19H22O6) influence cell enlargement and stem elongation.

Abscisic acid: It is useful in embryo culture and somatic embryogenesis.

Ethylene $\left(\mathrm{C}_{2} \mathrm{H}_{4}\right)$ : It is a gas produced by plants. It is involved with fruit ripening, flowering and leaf abscission.

\section{Materals \& Methods}

Media $\rightarrow$ a. Macronutrients: Nitrogen, Phosphate, Potassium, Magnessium, Calcium, etc.

b. Micronutrients: Iron, Cobalt, Molybdenum, Manganese, Nickel, Copper,etc.

Vitamins $\rightarrow$ B-group vitamins.

Nitrogen $\quad$ Sources $\rightarrow \quad$ Ammonium compounds or Nitrates.

Carbohydrate Sources $\rightarrow$ Sucrose \& Inositol.

Growth hormones $\rightarrow$ a. Auxin: IAA, IBA, NAA, 2,4-D

Kinetin, Zeatin, D-Biotin.

b. Cytokinin: BA,

c. Others: Adenine sulfate, GA3, Ca-Pentathenate

Solidifying Agent $\rightarrow$ Agar-agar

Reagents $\rightarrow 70 \%$ alcohol, $0.1 \%$ Mercuric chlorides, Tween-20, $0.5 \%$ Bavistin, Labolene, Coconut water $(150 \mathrm{ml} / \mathrm{l})$.

Selection of explant $\rightarrow$ Plant selected for tissue culture studies was Vanilla Planifolia. Part of nodal section with bud was selected and as an explant for shoot multiplication.

\section{Preparation and sterilization of explant}

The nodes of Vanilla planifolia was taken from the botanical garden of pocha, Pune. The nodal parts of plants of plants were washed thoroughly in sterilized double distilled water. Treated for sterilization given as, $70 \%$ alcohol in 30 sec. Washed with sterilized double distilled water for 2-3 sec. Explants suspended $0.1 \% \mathrm{HgCl} 2$ with tween-20 (2 drops) for $10 \mathrm{~min}$. Again washed with sterilized double distilled water, then suspended in $0.5 \%$ bavistin for 5 min. Finally, explants were thoroughly washed in distilled water for several times.

Preparation of glasswares $\rightarrow$ All the glasswares required for tissue culture studies like Test tubes, conical flask, etc. were soaked in $1 \mathrm{~N}$ HCL for $48 \mathrm{hrs}$ and then washed with laboline, rinsed with distilled water and air dried. After air drying, these glassware transferred in over for heat sterilization at $150^{\circ} \mathrm{C}$ for $8 \mathrm{hrs}$ before use.

\section{Preparation of culture media}

Macronutrient (Stock-A): $\mathrm{MgSO}_{4} \cdot 7 \mathrm{H}_{2} \mathrm{O}$, $\mathrm{KH}_{2} \mathrm{PO}_{4}, \mathrm{KNO} 3, \mathrm{NH} 4 \mathrm{NO} 3, \mathrm{CaCl}_{2}, 2 \mathrm{H}_{2} \mathrm{O}$ were weighted in required quantity. Micronutrient was dissolved in $500 \mathrm{ml}$. of distilled water and mixed together. Sulphate, Phosphate compounds were nitrates calcium 
compounds were dissolved separately then mixed together to make final volume to avoid precipitation of salts. Final volume was adjusted with distilled water to one liter.

Micronutrients (Stock-B): $\mathrm{H}_{3} \mathrm{BO}_{3}, \mathrm{MnSO}_{4}$. $4 \mathrm{H}_{2} \mathrm{O}, \quad \mathrm{NaMoO}_{4} \cdot 2 \mathrm{H}_{2} \mathrm{O}, \quad \mathrm{CuSO}_{4}, \quad 5 \mathrm{H}_{2} \mathrm{O}$, $\mathrm{CoCl}_{2}, 6 \mathrm{H}_{2} \mathrm{O}$, KI were weighted in required quantity and dissolved in $500 \mathrm{ml}$ of distilled water sequentially. Final volume $1000 \mathrm{ml}$. was adjusted with distilled water.

Iron (Stock-C): $\mathrm{FeSO}_{4} . \quad 7 \mathrm{H}_{2} \mathrm{O}$ was dissolved in $100 \mathrm{ml}$ double distilled water $\mathrm{Na}_{2}$ EDTA was also dissolved separately in $100 \mathrm{ml}$. distilled water. NaEDTA solution was boiled and to if $\mathrm{FeSO}_{4}$ solution was gently added. Final volume was made 1 liter.

Vitamins (Stock-D): Thiamine -HCL, Pyrimidine -HCL, Nicotinic acid, Glycine were weighted in required quantity. All the weighted vitamins dissolved in separately in $100 \mathrm{ml}$. of distilled water then mixed together. Final Volume was adjusted to $1000 \mathrm{ml}$ with distilled water.

Growth regulators: BA, Kinetin, 2,4-D, IAA, IBA were weighted appropriate quantity (100mg) and initially dissolved in few drops of $0.1 \mathrm{~N} \mathrm{NaOH}$. Final volume (100ml) was made using distilled water, comprising the final concentration of each stock of growth hormones to $1 \mathrm{mg} / \mathrm{ml}$.

Culture medium: MS medium is widely used and applicable plant tissue culture medium used in the present study. The major constituents of MS medium include:

The Micronutrients, micronutrients \& vitamins drawn from the stock solution were mixed in required quantity. The substances were added as necessary. Sucrose as a source of energy was dissolved $30 \mathrm{~g} / 1(3 \%)$.
The final volume of known quantity was obtained by adding double distilled water. The $\mathrm{pH}$ was adjusted to 5.8 by addition of $1 \mathrm{~N} \mathrm{HCL}$ or $\mathrm{NaOH}$ as required.

Agar-agar was added to the boiling media at a rate of $8 \mathrm{~g} / 1(0.8 \%)$ slowly and gradually with constant stirring to avoid formation of any clumps. Then the medium was dispensed into cultured vessels, i.e. glass bottles (baby jars of $300 \mathrm{ml}$. capacity) or test tubes $(25 \mathrm{X} 150 \mathrm{~mm}$. size) at a rate $0.40 \mathrm{ml}$ and $15 \mathrm{ml}$ respectively. These vessels were plugged with polypropylene caps and were then autoclaved along with petri dishes and other surgical instruments required for transferred operation $121^{\circ} \mathrm{C}$ and at a pressure of $1.2 \mathrm{~kg} / \mathrm{cm}(151 \mathrm{bs})$ for 20 minutes.

Working Solution: (For 1000ml)

\section{For shoot induction and shoot multiplication}

$\begin{array}{llc}\text { Stock A }(10 \mathrm{x}) & : & 100 \mathrm{ml} \\ \text { Stock B }(200 \mathrm{x}) & : & 5 \mathrm{ml} \\ \text { Stock C (200x) } & : & 5 \mathrm{ml} \\ \text { Stock D }(10 \mathrm{x}) & : & 5 \mathrm{ml} \\ \text { Sugar }(3 \%) & : & 30 \mathrm{~g} \\ \text { pH } & : 5.8 \pm 0.2\end{array}$

made volume $1000 \mathrm{ml}$ with double distilled water. Then Agar (0.8\%) $8 \mathrm{~g}$ is added as a solidifying agent. Agarified media was dispensed in culture tubes $(\sim 20 \mathrm{ml} /$ tubes $)$. This medium is autoclaved at $121^{\circ} \mathrm{C} / 15 \mathrm{lbs}$ for 20 minutes.

MS basal medium: (For $1000 \mathrm{ml}$ )

$\begin{array}{llc}\text { IAA } & : & 2 \mathrm{mg} / \mathrm{lit} \\ \text { Kinetin } & : & 0.5 \mathrm{mg} / \mathrm{lit} \\ \text { BAP } & : & 0.5 \mathrm{mg} / \mathrm{lit} \\ \text { D-Biotin } & : & 0.2 \mathrm{mg} / \mathrm{lit} \\ \text { Ca-pentatrenate } & : & 0.2 \mathrm{mg} / \mathrm{lit} \\ \text { Agar } & : & 8 \mathrm{gm} \\ \text { Sucrose } & : & 30 \mathrm{gm}\end{array}$


MS basal medium: (For 1000ml)

$\begin{array}{lcc}\text { BAP } & : & 1.0 \mathrm{mg} / \mathrm{lit} \\ \text { Coconut water } & : & 150 \mathrm{ml} / \mathrm{lit} \\ \text { Agar } & : & 8 \mathrm{gm} \\ \text { Sucrose } & : & 30 \mathrm{gm}\end{array}$

MS Basal Medium: (For $1000 \mathrm{ml}$ )

$\begin{array}{llc}\text { BAP } & : & 0.5 \mathrm{mg} / \mathrm{lit} \\ \text { Agar } & : & 8 \mathrm{gm} \\ \text { Sucrose } & : & 30 \mathrm{gm}\end{array}$

\section{Preparation of Chamber for inoculation}

Aseptic culture work like final surface sterilization of plant material preparation and inoculation of explants, and further subculturing of in vitro cultures were carried out in a Laminar air flow cabinet.

Before preparing the explant for culturing, the inoculation chamber or laminar flow was setup. The entire laminar flow was cleared with absolute alcohol from inside and outside. Test tube containing autoclaved culture media, sterilized petri dishes, beakers, forceps, scalpels sterile distilled water aqueous $0.5 \% \mathrm{HgCl} 2$ Sprit lamp, etc. were kept for a surface sterilization under UV lamp for about half an hour before inoculation was carried out. After switching off the UV lamp, laminar flow was put on.

\section{Culture Conditions}

All the cultures were maintained at $25 \pm 2^{\circ} \mathrm{C}$ with $80-90 \%$ humidity. The light requirements have been met with florescent tubes with incandescent lamps. The light sources were held at a constant distance so that the culture should receive 2000 lux light.
Data collection: Observations were made for 4 weeks after inoculation.

\section{Results \& Discussions}

Experiments were conducted to study the effect of different growth regulators with nutrient media on establishment and subsequent growth and development of plantlets buds in Vanilla. The results are presented under the respective characters genus vanilla. The results are presented under the respective characters. Genus Vanilla shows more response of growth and multiplication.

\section{Affects of growth regulators}

Number of days taken for establishment of explants (axillary buds) $\rightarrow$ The mean time taken for establishment i.e. response of axillary buds was early is 5 days in medium supplemented with $0.5 \mathrm{mg} / \mathrm{l}$. BAP and 4 days in medium supplemented with $1.0 \mathrm{mg} / \mathrm{l}$. $\mathrm{BAP}+$ Coconut Water $(1.5 \%)$ and in medium supplemented with IAA $2 \mathrm{mg} / \mathrm{l}$.+ Kinetin $0.5 \mathrm{mg} / \mathrm{l}$. +BAP $0.5 \mathrm{mg} / \mathrm{l} .+$ D-Biotin $0.2 \mathrm{mg} / \mathrm{l}$. + Ca-pentathenate $0.2 \mathrm{mg} / \mathrm{l}$. In vitro shoot induction was observed when the nodal explants were cultured on MS medium supplemented with different growth regulator in different combinations. Similar results obtained by Washeem et. al.(2011), when the combination of different concentrations of NAA and BAP were used, significant results regarding intermediate concentration of regeneration of chrysanthemum plantlets were achieved. MS media supplemented with lower concentrations of NAA $(0.5$ and $1.0 \mathrm{mg} / \mathrm{L})$ and BAP (1.0 and $1.5 \mathrm{mg} / \mathrm{L})$ showed better results as compared to other concentrations and combinations. 
Table.1 Composition of MS medium with different concentrations used in the tissue culture of Vanilla Planifolia.

\begin{tabular}{|c|c|c|c|}
\hline Stock Ingredients & $\begin{array}{l}\text { Concentrations in } \\
\text { stock solution (mg/l) }\end{array}$ & $\begin{array}{l}\text { Volume of stock (ml) } \\
\text { in final solution (1liter) }\end{array}$ & $\begin{array}{l}\text { Final concentration in } \\
\text { medium }(\mathrm{mg} / \mathrm{l})\end{array}$ \\
\hline \multicolumn{4}{|l|}{ Stock-I (10x) } \\
\hline $\mathrm{NH}_{4} \mathrm{NO}_{3}$ & 14000 & 100 & 1400.00 \\
\hline $\mathrm{KNO}_{3}$ & 17000 & & 1700.00 \\
\hline $\mathrm{CaCL}_{2} \cdot 2 \mathrm{H}_{2} \mathrm{O}$ & 4400 & & 440.00 \\
\hline $\mathrm{KH}_{2} \mathrm{PO}_{4}$ & 1700 & & 170.00 \\
\hline $\mathrm{MgSO}_{4} \cdot 7 \mathrm{H}_{2} \mathrm{O}$ & 3700 & & 370.00 \\
\hline \multicolumn{4}{|l|}{ Stock- II (200x) } \\
\hline KI & 166 & 5 & 0.830 \\
\hline $\mathrm{H}_{3} \mathrm{BO}_{3}$ & 1240 & & 6.2 \\
\hline $\mathrm{MnSO}_{4} \cdot 7 \mathrm{H}_{2} \mathrm{O}$ & 4460 & & 22.30 \\
\hline $\mathrm{ZnSO}_{4} .7 \mathrm{H}_{2} \mathrm{O}$ & 1720 & & 8.60 \\
\hline $\mathrm{Na}_{2} \mathrm{MoO}_{4} \cdot 2 \mathrm{H}_{2} \mathrm{O}$ & 5 & & 0.25 \\
\hline $\mathrm{CuSO}_{4} .7 \mathrm{H}_{2} \mathrm{O}$ & 5 & & 0.025 \\
\hline $\mathrm{CoSl}_{2} \cdot 2 \mathrm{H}_{2} \mathrm{O}$ & 5 & & 0.025 \\
\hline \multicolumn{4}{|l|}{ Stock - III (200x) } \\
\hline $\mathrm{FeSO}_{4} .7 \mathrm{H}_{2} \mathrm{O}$ & 4785 & 5 & 13.90 \\
\hline $\mathrm{Na}_{2}$ EDTA & 3725 & & 18.50 \\
\hline \multicolumn{4}{|l|}{ Stock - IV (200x) } \\
\hline Myoinositol & 20000 & 5 & 100.00 \\
\hline Thiamine HCL & 20 & & 0.1 \\
\hline Pyridoxine HCL & 100 & & 0.5 \\
\hline Nicotinic acid & 100 & & 0.5 \\
\hline Glycine & 400 & & 2.0 \\
\hline
\end{tabular}

Table.2 Affects of various media on shoot induction \& growth of leaves

\begin{tabular}{|l|l|l|}
\hline Trials & Media used & $\begin{array}{l}\text { Shoot induction \& Average } \\
\text { number of leaves }\end{array}$ \\
\hline 1. & MS Basal + BAP 0.5 mg/1 & 2 \\
\hline 2. & MS Basal + BAP $1.0 \mathrm{mg} / 1$ & 1 \\
\hline 3. & MS Basal + BAP 0.5 + NAA 0.5 mg/1 & 1 \\
\hline 4. & MS Basal + BAP 0.5 + NAA 0.5 mg/1 & 1 \\
\hline 5. & $\begin{array}{l}\text { MS Basal + IAA 2mg/1 +kinetin 0.5mg/lit } \\
+ \text { BAP 0.5 mg/lit + D-biotin 0.2mg/lit + ca- } \\
\text { pentatrenate 0.2mg/lit 8gm agar + 30gm } \\
\text { Sucrose }\end{array}$ & \\
\hline
\end{tabular}


Table.3 Affect of different concentrations of plant growth regulators in coconut water (CW) on in Vitro development of Vanilla plantlet

\begin{tabular}{|l|c|c|}
\hline Concentrations & \% of explants forming shoots & No. of leaf formation \\
\hline $0.5+\mathrm{CW}$ & 80 & 5 \\
\hline $1.0+\mathrm{CW}$ & 100 & 7 \\
\hline $1.5+\mathrm{CW}$ & 75 & 4 \\
\hline $2.0+\mathrm{CW}$ & 70 & 3 \\
\hline $2.5+\mathrm{CW}$ & 65 & 2 \\
\hline $3.0+\mathrm{CW}$ & 40 & 1 \\
\hline
\end{tabular}

Fig.1 Shoot induction showing formation of number of leaves with various combinations of growth regulators

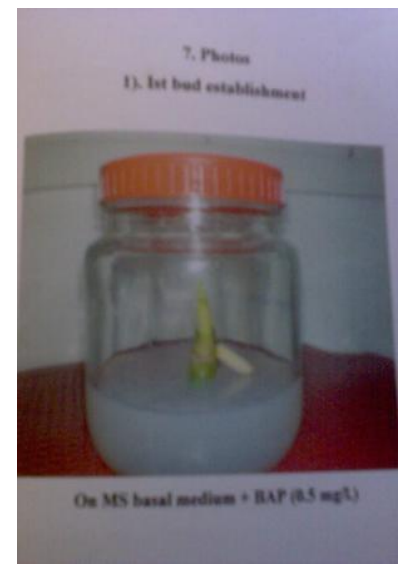

a) On MS medium + BAP $(0.5 \mathrm{mg} / \mathrm{l})$

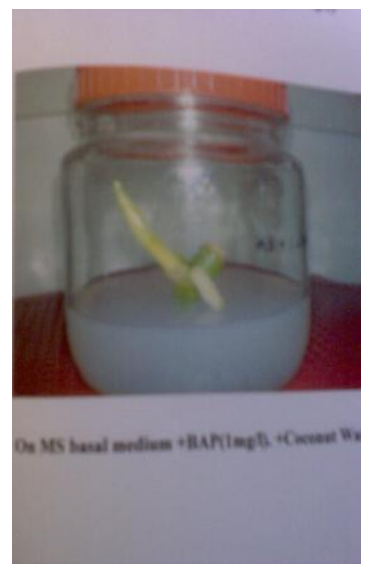

b) On MS medium + BAP (1mg/l) + CW

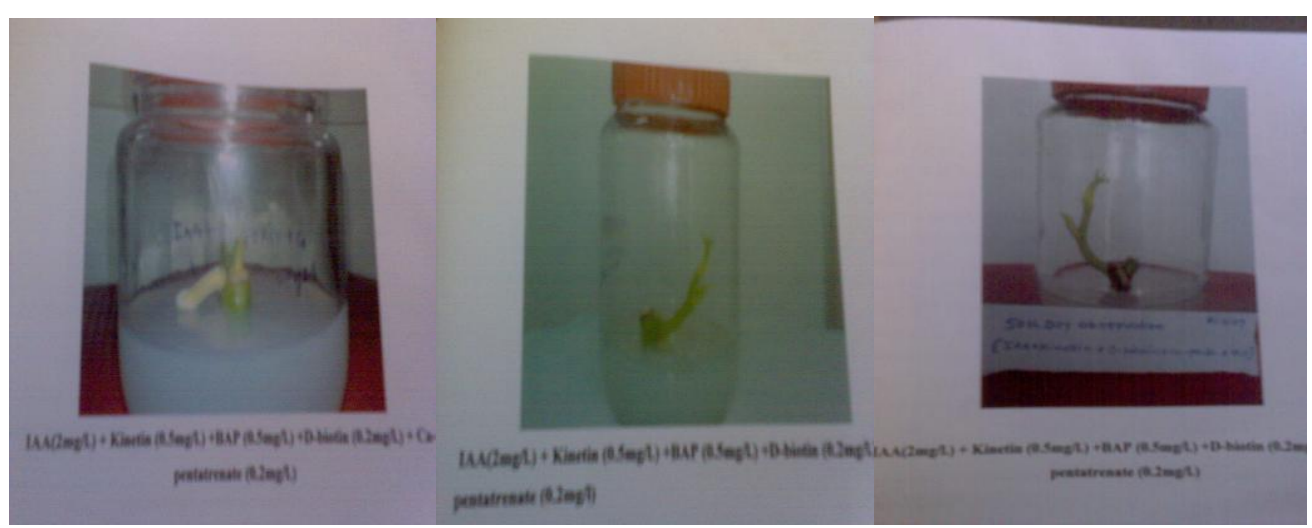

c) IAA $(2 \mathrm{mg} / \mathrm{l})+$ Kinetin $(0.5 \mathrm{mg} / \mathrm{l})+$ BAP $(0.5 \mathrm{mg} / \mathrm{l})+\mathrm{D}$-biotin $(0.2 \mathrm{mg} / \mathrm{l})+$ Ca-pentatartarate $(0.2 \mathrm{mg} / \mathrm{l})$. 


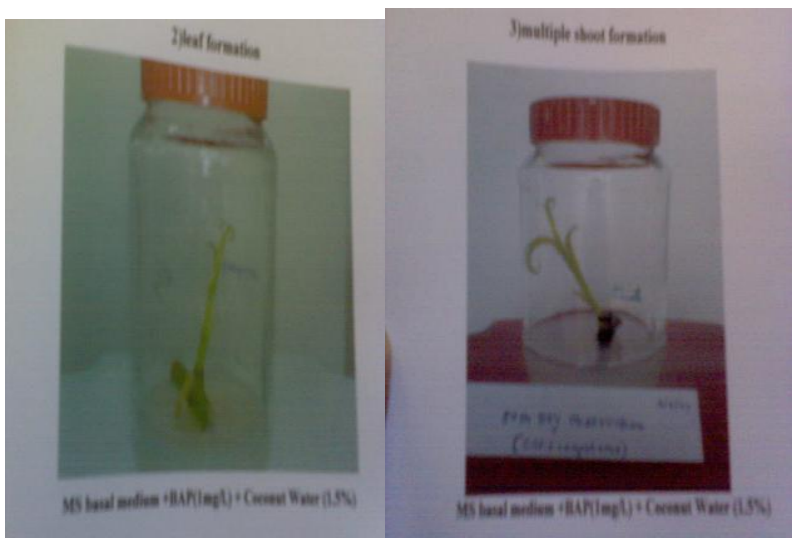

d) MS medium + BAP (1mg/l) +CW (1.5\%)

Number of days taken for emergence of first leaf $\rightarrow$ The mean number of days taken for emergence of first leaf was 8 days in medium. Which is supplemented with $0.5 \mathrm{mg}$ BAP and 6 days in medium supplemented with different growth regulator combinations. Also, in the experiments of others (Washeem et al., 2011) BAP had produced maximum shoot initiation, shoot per explant, length of shoots, number of leaves (11) and nodes.

Multiple shoots $\rightarrow$ The shoot multiplication was observed on sub-culturing the different combinations of BA i.e. $0.5 \mathrm{mg} / 1$ with $\mathrm{MS}$ basal medium, minimum number of multiple shoot recorded in this media and the medium supplemented with IAA $2 \mathrm{mg} / \mathrm{l}$. + Kinetin 0.5mg/l. + BAP 0.5mg/l. + D-Biotin $0.2 \mathrm{mg} / 1$.+Ca-pentathenate $0.2 \mathrm{mg} / \mathrm{l}$. shows well shoot multiplication than other BA combination, maximum number of multiple shoots in these two media.

Optimization $\rightarrow$ The result of the experiments pertaining to the effect of MS medium with different concentrations of plant growth regulators, BAP in combination with Coconut Water was prepared and explant was established invitro and further growth and development of plantlets in vanilla.

\section{References}

Bai, Y., Qu, R. 2001. Factors influencing tissue culture responses of mature seeds and immature embryos in turftype tall fescue. Plant Breeding, 120(3): 239-242.

Carlson, P.S., Harold, H.S. \& Dearing, R.D. 1972. Parasexual inerspecific plant hybridization. Proc. Nat. Acad. Sci. USA, 69(8): 2292-2294.

Chin, Yi, Lu. 1993. The use of thidiazuron in tissue culture. In vitro cell. Biol., 29: 92-96.

Cocking, E.C. 1999. Turning point aricle plant protoplast, In Vitro Cell. Dev. Biol-Plant, 36: 77-88.

Flick, C.E., Evans, D.E. \& Sharp, W.R. 1983. Organogenesis. In Handbook of Plant Cell Culture, Vol 1. D.A. Evans, W.R. Sharp, P.V. Ammirato, and Y. Yamada, eds (New York: Macmillan), pp. 13-81.

George, EL., Hall, M.A. \& De-Klark, G.J. 1964. Plant propagation by tissue culture ( $3^{\text {rd }}$ edition), 118-500.

Haberlandt, G. 1902. Culturversuche mit isolierten Pflanzenzellen. Sitz-Ber. Mat.-Nat. K1. Kais. Akad.Wiss. Wien. 111(1): 69-92.

Kumar, Manilal. 1994. A catalogue of 
Indian Orchids.

Murashige, T., Skoog, F. 1962. A Revised medium for rapid growth and bio assays with tobacco tissue cultures. Physiologia Plantarum, 15(3): 473497.

Skoog, F., Miller, C.O. 1957. Chemical regularion of growth and organ formation in plant fissue cultured. In vitro. Symp. Soc. Exp. Biol., 11: 118131.

Vasil, K. \& Hildebrandt, A.C. 1966. Variations of Morphogenetic Behavior in Plant Tissue Cultures. I. Cichorium endivia. American J. Bot., 53(9): 860869.

Washeem, K., Salimjilani, M., Jaskani, M. \& Ullahkhan. 2011. Significance of different plant growth regulators on the regeneration of chrysanthemum plantlets (Dendranthema morifolium L.) through shoot tip culture. Pak. J. Bot., 43(4): 1843-1848.

Wickson, M. \& Thimann, K.V. 1958. The antagonism of auxin and kinetin in apical dominance. Physiologia Plantarum, 11: 62-74.

\section{How to cite this article:}

Vijaykumar Biradar, Ashashree Inamdar, Aswini Shamse \& M.S. Patil. 2016. In Vitro Studies on the Influence of Different Concentrations of Growth Regulators on Economically Important Orchid, Vanilla planifolia. Int.J.Curr.Microbiol.App.Sci. 5(9): 311-323. doi: http://dx.doi.org/10.20546/ijcmas.2016.509.035 